\title{
RESIN ACIDS IN BILE SAMPLES FROM FISH INHABITING MARINE WATERS AFFECTED BY PULP MILL EFFLUENTS
}

\author{
VÍCTOR HERNÁNDEZ ${ }^{* 1}$, MARIO SILVA', JUAN GAVILÁN ${ }^{2}$, \\ BEGOÑA JIMÉNEZ ${ }^{4}$ RICARDO BARRA ${ }^{3}$, AND JOSÉ BECERRA ${ }^{l}$
}

\begin{abstract}
${ }^{1}$ Laboratorio de Química de Productos Naturales, Departamento de Botánica, Facultad de Ciencias Naturales y Oceanográficas, Universidad de Concepción, Casilla 160-C, Concepción, Chile

${ }^{2}$ Departamento de Biología Celular, Facultad de Ciencias Biológicas, Universidad de Concepción, Chile

${ }^{3}$ Unidad de Investigación en Sistemas Acuáticos, Centro de Ciencias Ambientales, EULA-Chile, Universidad de Concepción, Chile

${ }^{4}$ Departamento de Análisis Instrumental y Química Ambiental, Instituto de Química Orgánica General, CSIC, Madrid, Spain

(Received: February 25, 2008 -Accepted: July 29, 2008)
\end{abstract}

\begin{abstract}
Cellulose production in Chile has increased noticeably during recent years. Some pulp mill currently released effluents into the ocean, a trend that most these plants seem likely to continue in the future. No standardized protocols exist for evaluating potential environmental effects of such dumping in the marine environment. Resin acids, typical components in cellulose effluents, are known to be highly toxic, particularly for fish. Few investigations have considered this matter for the south area of Golfo de Arauco, one of the most productive areas on the planet in terms of fisheries. This area is currently subjected to effluent dumping from a kraft cellulose industry with secondary treatment. Resin acids are naturally present in conifer wood, making these compounds useful markers for exposure to this type of effluent. Herein, we report the presence of these compounds in bile from two fish species (Paralychtys adspersus and Paralychtys microps) caught in two seasons in the Bahía de Horcones at the southern mouth of Golfo de Arauco, central Chile, an area affected by cellulose effluent dumping. Dehydroabietic acid (17,5 ug/g in average) was found in the bile samples of the fish.
\end{abstract}

Keywords: Resin acids, bile flounder, cellulose effluents, Golfo de Arauco, Chile.

\section{INTRODUCTION}

Golfo de Arauco (Fig. 1), located between $37^{\circ} 10^{\prime}$ 'S and $36^{\circ} 45^{\prime}$ 'S off centralsouthern Chile, is known to be one of the most productive areas of the planet ${ }^{1}$, constituting an area of particular commercial interest due to the extraction of shellfish and fish used for human and industrial consumption. Nevertheless, to date, few studies have been done in the southern mouth of the Gulf ${ }^{2}$, where the effluents of an important kraft cellulose industry are dumped.

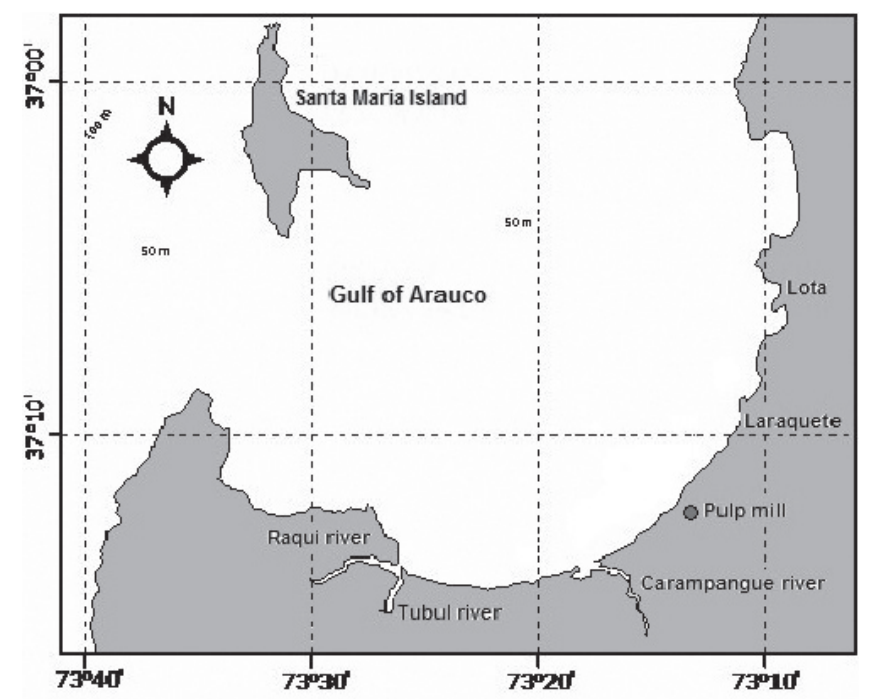

Figure 1. Study area, Bahìa de Horcones, southern mouth, Golfo de Arauco, central Chile.

Since the early 1980s, a wide range of harsh environmental effects has been discovered related to cellulose effluents, indicating the highly polluting nature of this activity 3,4 . In recent years, most of these effects have been studied at sub-lethal concentrations ${ }^{5}$, as technological advances have resulted in the decreased use of chlorinated compounds for pulp bleaching processes. The effluents and process waters in the cellulose industry are complex, containing an important number of chemical compounds, some of which are known for their high toxicity. Treatments have significantly reduced these compounds and, consequently, their toxic effects. However, the chronic toxicity of the effluents is known to be directly related to the presence of resin acids 5,6 .

Resin acids are tricyclic diterpenes that are present naturally in wood and frequently in conifers. These acids are released during pulping processes and are very resistant to the alkaline chemical digestion of the wood. The most common resin acids found in conifers include the pimarane and abietane type acids ${ }^{7}$ (Fig. 2). The abietane-type acids (with conjugated double bonds) are more favorable to degradation than the pimarane-type acids (without conjugated double bonds); bacteria such as Pseudomonas abietaniphila are responsible for this degradation ${ }^{8,9}$.

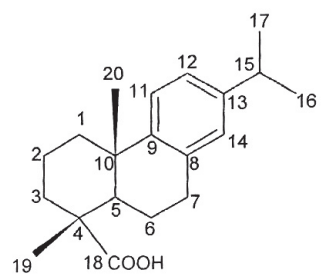

Dehydroabietic acid

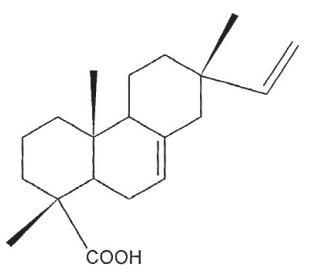

Isopimaric acid

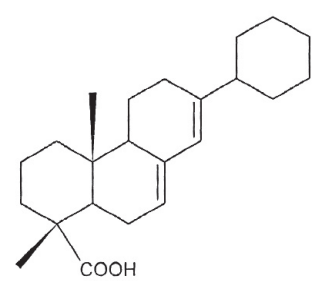

Abietic acid

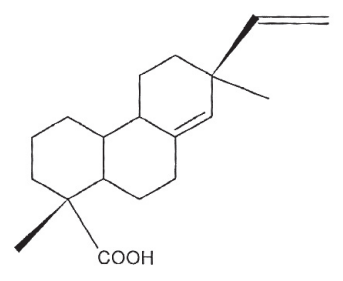

Pimaric acid
Figure 2. Resin acids determined by GC-MS in flounder bile.

The high toxicity of resin acids for fish populations has been known for a long time ${ }^{10}$. In spite of these well-grounded suspicions indicating that resin acids, specifically abietic acid, are responsible for the observed reproductive effects in the fish, it has not been possible to determine whether these are due directly to the effluents or to some chemical reaction external to the pulping process occurring in the receptive bodies where the residual waters are released ${ }^{11}$. 
Resin acids are lipophilic and dehydroabietic acid has an octanol/water partition coefficient $\left(\log \mathrm{K}_{\mathrm{ow}}\right)$ of $1.74{ }^{12}$. This characteristic allows these acids to adsorb rapidly onto suspended solids in the effluent treatment systems and in the receiving aquatic systems, thereby causing the resin acids to become bioconcentrated in the fish to a greater degree than in the water; the concentration factors in fish blood and liver plasma are over 100 fold ${ }^{13}$.

Fish can excrete organic pollutants through a variety of routes, including gills, skin, mucus, bile, urine and feces ${ }^{14}$. An efficient way to evaluate the degree of exposure of a fish to a certain pollutant and to indirectly estimate the degree of bioavailability of acid resins is to measure the concentration of the compounds or its metabolites in the bile fluids ${ }^{6,10,15,16}$.

The most important sites for the toxic action of these pollutants in fish are the gills ${ }^{14}$, erythrocytes ${ }^{17}$, and hepatocytes ${ }^{12}$. Lindesjöö et al. (2002) showed the presence of resin acids in fish bile due to continued exposure to treated totally chlorine free cellulose effluents even around two months of recuperation ${ }^{18}$.

Resin acids can be removed from the effluents by bacterial degradation, adsorption onto particulate material, or dilution with the latter reported as the most likely mechanism for decreasing the concentrations of these metabolites. In spite of degradation by microorganisms has been a slower process, is effective to achieve this objective ${ }^{19,20}$.

Up to day, most of the research carried out in relation to the effect of resin acids in fish has been done in rivers ${ }^{13,21,22,23}$ and lakes ${ }^{6}$; few studies have been done on marine fish ${ }^{2,24,25}$.

George-Nascimento et al.(2000) $)^{2}$ studied samples of female flounders (Paralychtys microps, Paralychtys adspersus) that were caught in three bays exposed to anthropogenic intervention in the region. These authors found clear evidence of altered states of health in the specimens captured around the sites where treated cellulose effluents are evacuated (Bahía de Horcones). All the fish that were caught in this bay $(100 \% ; \mathrm{n}=20)$ had necrotic damage on the skin and fins; these were compared with samples taken from a clean reference area. Moreover, the increased values in the hepatosomatic, splenosomatic and ovariosomatic indices were verified in comparison to the reference area, with a significant decrease in the condition factor, quantity of hemoglobin $(\mathrm{g} \%)$, total proteins $(\mathrm{g} \%)$, and lymphocytes (lymphocytes $* 1000$ erythrocytes). This agrees with other data that show high mixed-function oxidase (MFO) levels for species caught in the Horcones area (Hernández, 2007, unpublished data).

The present study reveals abietic, pimaric, dehydroabietic and isopimaric acids in the bile of the flounder caught in the Horcones area of Golfo de Arauco, central Chile, using chromatographic techniques.

\section{MATERIAL AND METHODS}

\subsection{Study area and species}

Two species of flounder (P. microps, P. adspersus) were caught with nets in April $2005(\mathrm{n}=9$; B1-B9) and January $2006(\mathrm{n}=5$; B10-B15) in the Horcones area of the southern mouth of Golfo de Arauco (Fig 1). The specimens were transported to the laboratory in sea water under controlled conditions. The intense wind and strong marine currents around the shoal at the beach in the Horcones sector (Bahía de Horcones) were the most likely cause for the low number of species sampled. Samples $(n=5)$ of the same flounder species were caught off Dichato, in Bahía de Coliumo; this area was used as a reference for this study.

\subsection{Methods}

The bile vesicles were removed from the 14 flounder specimens and refrigerated in Eppendorff-type tubes, where they were kept until their extraction.

Resin acid (abietic, neoabietic, pimaric, isopimaric, dehydroabietic) standards (Helix Biotech) were kindly provided by Professor Margaretha Adolfsson-Erici (Departament of Applied Sciences, Stockholm University). The $\beta$-glucuronidase enzyme ( 101,200 units $/ \mathrm{mL}$ with 290 units of sulfatase $/ \mathrm{mL}$ ) was acquired from Sigma-Aldrich. The solvents (p.a.) used in the extraction processes and chemical analyses were obtained from Merck. The extraction and analysis of the resin acids in fish bile fluid were carried out according to the method described by Adolffsson-Erici in $2005^{16}$. The bile fluid was first weighed in small amber glass flasks and then diluted in acetate buffer $(\mathrm{pH} 5$, $0.2 \mathrm{M}$ ). Later, $20 \mu \mathrm{L}$ of the $\beta$-glucuronidase enzyme were added to this solution and the samples were incubated all night at $37^{\circ} \mathrm{C}$. The free compounds were then removed through successive extractions with hexane:methyl-tert-butylether (1:1) and $2 \mathrm{~mL}$ of Milli-Q water were added. The emulsion in the extracts was eliminated by adding sodium chloride to the solution. Once the three organic phases were combined, they were centrifuged and later evaporated to dryness with nitrogen current.

The resin acids were determined as their methylated esters. Diazomethane $(50 \mu \mathrm{L})$ dissolved in ether was added to the concentrated samples and the tubes were covered and incubated for $60 \mathrm{~min}$ at $40{ }^{\circ} \mathrm{C}$. This solution was again subjected to a nitrogen current and resuspended with isooctane prior to its chromatographic determination. Chromatographic runs were also carried out with blanks and original standards of each resin acid (Helix Biotech).

The samples were analyzed with GC-MS, using a Hewlett Packard Mod. 5890 Series II with mass detector Hewlett Packard Mod. 5972 Series equipped with a 30-m HP-5 MS column (J\&W Scientific) and using a GC Agilent Mod. $6890 \mathrm{~N}$ equipped with a flame ionization detector (FID) and 30-m HP5 column (J\&W Scientific). Both columns have an internal diameter of $0.25 \mathrm{~mm}$ and a phase thickness of $0.25 \mu \mathrm{m}$. The identities and concentrations of the extracted compounds were determined by GC chromatography. Gas chromatography with FID detection was used to corroborate the identity and concentration of resin acids in the samples.

Each one of the extracts was injected into both chromatographs in splitless mode with the following temperature program: $1 \mathrm{~min}$ at $100^{\circ} \mathrm{C}$, with increments of $15^{\circ} \mathrm{C} / \mathrm{min}$ to $180^{\circ} \mathrm{C}$ and with increments of $30^{\circ} \mathrm{C} / \mathrm{min}$ to $300^{\circ} \mathrm{C}$. The injector temperature was $250^{\circ} \mathrm{C}$ and the detector temperature was $300^{\circ} \mathrm{C}$. The source of ions for the mass detector was maintained at $70 \mathrm{eV}$ in full scan and SIM mode.

The resin acid identities were determined using the NIST98 (NIST/EPA/ NIH Mass Spectral Library) and the NBS75K (Hewlett Packard Mass Spectral Library) data bases for GC-MS and compared with authentic standards according to their retention times and mass spectrum.

\section{RESULTS AND DISCUSSION}

The resin acids in the fish bile were identified and quantified as shown in Table 1. The detection limit for this analysis was calculated as $0.05 \mu \mathrm{g} / \mathrm{g}$.

Table 1: Total resin acid values reported in Golfo de Arauco $(\mu \mathrm{g} / \mathrm{g})$.
\begin{tabular}{|l|l|l|l|l|l|l|l|l|l|l|l|}
\hline Samples & B1 & B2 & $\begin{array}{l}\text { B3+ } \\
\text { B4 }\end{array}$ & $\begin{array}{l}\text { B5+ } \\
\text { B6 }\end{array}$ & B-7 & B-8 & B-9 & B-10 & B-11 & $\begin{array}{l}\text { B12+ } \\
13\end{array}$ & B-14 \\
Resin acids & 7.3 & 8.6 & 16.3 & 17.2 & 5.2 & 3.6 & 5.4 & 4.7 & 5.5 & 6.5 & 4.1 \\
\hline Abietic & 3.8 & 4.1 & 6.6 & 8.0 & 3.1 & 2.3 & 4.2 & 5.1 & 4.3 & 5.3 & 5.2 \\
\hline Pimaric & 23.2 & 27.0 & 3.9 & 4.8 & 25.1 & 29.5 & 20.1 & 19.4 & 23.4 & 22.1 & 20.3 \\
\hline Dehydroabietic & 2.3 & 2.2 & 3.7 & 4.9 & 1.4 & 1.6 & 2.2 & 1.9 & 2.1 & 1.9 & 2.1 \\
\hline Isopimaric & 36.6 & 41.9 & 30.5 & 34.9 & 34.8 & 37.0 & 31.9 & 31.1 & 35.3 & 35.8 & 31.7 \\
\hline Total resin & & & & & & & & & & \\
\hline
\end{tabular}

The presence of a pollutant in the fluids and tissues of an animal indicates that these elements are bioavailable from their source of origin for the biota under study.

Table 2: Resin acid values reported in the reference area $(\mu \mathrm{g} / \mathrm{g})$.

\begin{tabular}{|l|l|l|l|l|}
\hline $\begin{array}{l}\text { Reference samples } \\
\text { Resin acids }\end{array}$ & B1 & B2+B3 & B4 & B5 \\
\hline Abietic acid & ND & ND & ND & ND \\
\hline Pimaric acid & ND & ND & ND & ND \\
\hline Dehydroabietic acid & ND & ND & 0.08 & ND \\
\hline Isopimaric acid & ND & ND & ND & ND \\
\hline
\end{tabular}

ND : Not detected. Detection limit : $0.01 \mu \mathrm{g} / \mathrm{g}$

The concentrations of the resin acids observed varied little in the two sampling periods. The observed constant level of dehydroabietic acid (average $17.5 \mu \mathrm{g} / \mathrm{g}$ ) coincided with previous references indicating that this is one of the main resin acids found in the effluents. On the other hand, given its concentration in the samples, we believe that dehydroabietic acid could have been produced by the transformation of other more soluble resin acids and, consequently, could be less toxic ${ }^{6}$. The decreased amount of abietic acid found in the second sample partially explains the slight increase in the average concentration of dehydroabietic acid. Nonetheless, in January and February, currents with different directions have been documented in the study area ${ }^{26}$. Therefore, it is not clear whether the decrease in abietic acid corresponds to a 
greater dilution associated with the varied current directions or some other cause such as a higher rate of transformation to dehydroabietic acid or even degradation due to the effect of more solar radiation ${ }^{27}$. In any event, a long-term sampling campaign is clearly necessary, as this would allow a better understanding of the behavior of these pollutants in the environment and their impact on the biota in the areas impacted by effluents from the cellulose industry, considering that the fish bile analyses are very sensitive biomarkers of pulp and paper mill effluents, due that the concentrations of resin acids and other toxicants can be 100-1000 times higher in bile than in water the fish live in. ${ }^{28}$

In only one sample of reference area (table 2) was detected a resin acid (dehydroabietic acid), which would be consistent with the presence of former saw mill in the area.

Because of its resistance to chemical or microbiological breakdown, dehydroabietic acid is a good chemical marker for the presence and effect of cellulose effluents. Nonetheless, resin acids in general can remain in the environment for a long time, being remobilized and constantly amplifying the effluents' range of impact ${ }^{22}$.

George-Nascimento et al. (2000) ${ }^{2}$ found signs of altered health in the flounder caught in this area. Given these results, we can state that persistent compounds can cause such alterations whenever they are identified in the bile of similar flounder species. Due to the frequency of the bile secretions involved in the digestive processes ${ }^{29}$, the identification of conjugated metabolites of resin acids in bile clearly indicates recent exposure to effluents derived from cellulose production. Previous studies 18,$6 ; 30,31$ have reported the presence of resin acids in diverse tissues and bile fluid (table 3 ).

Resin acids in fish can have many causes. Considering the persistence of these compounds - even when treatment processes result in noticeably decreased concentrations - certain events such as effluent spills or the dumping of process waters with important amounts of persistent compounds with recognized toxic effects should be responsible for the observed results ${ }^{32}$.

Table 3: Presence of resin acids in diverse tissues and in bile fluid of fish.

\begin{tabular}{|l|l|l|l|}
\hline \multicolumn{1}{|c|}{ Species and tissue or fluid } & \multicolumn{1}{|c|}{ Concentration } & \multicolumn{1}{c|}{ Observations } & \multicolumn{1}{c|}{ Reference } \\
\hline O. mykiss / bile & $\begin{array}{l}<200 \mu \mathrm{g} \text { dehydroabietic acid / g } \\
\text { bile fluid }\end{array}$ & $\begin{array}{l}\text { After } 57 \text { days of exposure to a } \\
\text { pulp mill effluent }\end{array}$ & Lindesjoo et al., 2002 \\
\hline R. rutilus / bile & $120 \mu \mathrm{g} / \mathrm{ml}$ total resin acids & $\begin{array}{l}\text { Exposure downstream of pulp } \\
\text { mill effluent }\end{array}$ & Leppanen and Oikari, 1999 \\
\hline P. fluviatilis / bile & $46 \mu \mathrm{g} / \mathrm{ml}$ total resin acids & $\begin{array}{l}\text { Exposure downstream of pulp } \\
\text { mill effluent }\end{array}$ & Leppanen and Oikari, 1999 \\
\hline O. mykiss / bile & $\begin{array}{l}13-620 \mu \mathrm{g} / \mathrm{g} / \text { brain tissue, } \\
\text { abietic and dehydroabietic acids }\end{array}$ & $\begin{array}{l}\text { Exposure to a range of } 12 \\
\text { until } 133 \mu \mathrm{M} \text { of abietic and } \\
\text { dehydroabietic acids. }\end{array}$ & Zheng and Nicholson, 1998. \\
\hline R. rutilus / bile & $320 \mu \mathrm{g} / \mathrm{mL}$ bile fluid & $\begin{array}{l}\text { Exposure downstream of pulp } \\
\text { mill effluent }\end{array}$ & Karels et al., 2001 \\
\hline P. fluviatilis / bile & $260 \mu \mathrm{g} / \mathrm{mL}$ bile fluid & $\begin{array}{l}\text { Exposure downstream of pulp } \\
\text { mill effluent }\end{array}$ & Karels et al., 2001 \\
\hline
\end{tabular}

\section{CONCLUSION}

Given the restricted range of movement for feeding in these flounder species and given the results of this study, flounder are appropriate bioindicators of exposure to this kind of organic pollutant.

The four resin acids determined in the bile of the fish caught in this study show that these compounds can be considered as evidence of its availability in the water column and in the sediments of Horcones Bay in the Gulf of Arauco, the habitat of diverse commercially important species and the site of treated waste dumped from one important pulp mill industry.

This contribution is the first report of resin acids in bile of fish living in the area surrounding a pulp mill in the Golfo de Arauco. A Further monitoring is, however, required to establish the tendencies in the bioaccumulation of this kind of xenobiotics in fish to define the long-term accumulation characteristics of resin acid from the sediments in the area adjacent to a pulp mill.

\section{ACKNOWLEDGMENTS}

This research was made possible thanks, in part, to the support of the Graduate School of the Universidad de Concepción, the EULA Center, and the Research Council of the Universidad de Concepción through internal project No. 204-37.11-1. We are particularly grateful to CSIC-CONICYT project No. 2005-157. The authors give special thanks to the assistance provided by the laboratory technician, Mr. Fabián Rozas, during sampling.

\section{REFERENCES}

1. Djurfeldt, L. Cont. Shelf Res. 9, 1003, (1989).

2. George-Nascimento, M., Khan, R., Garcias, F., Lobos, V., Muñoz, G., Valdebenito, V. Bull Environ. Contam. Toxicol. 64, 184-190, (2000).

3. Suntio, L., Wan, R., Shiu, Y., Mackay, D. Chemosphere, 17(7), 1249 -
(1988).

4. Owens, J. Environ. Toxicol. Chem. 10, 1511, (1991).

5. Tana, J. Water Sci. Technol. 20, 380, (1988).

6. Leppanen, H., Oikari, A. Environ. Toxicol. Chem. 18, 1498, (1999).

7. Sjostrom, E. Wood chemistry. Second edition. Academic Press, San Diego. U.S.A. Pp 289, 1993.

8. Mohn, W. W., Martin, V. J. J., Zhongtang, Y. Water Sci. Technol. 40, 273, (1999).

9. Liss, S. N., Bicho, P. A., Saddler, J. N. Can. J. Microbiol. 43, 599, (1997).

10 Leppanen, H., Marttinen, S., Oikari, A. Chemosphere 36, 2621, (1998).

11. Lehtinen, K., Jukka, T. The Finnish Environment Helsinski, Finland. 72 pp., 2001.

12. Nikinmaa, M., Wickström, C., Lilius, H., Isomaa, B., Rabergh, C. Environ. Toxicol. Chem., 18 (5), 993, (1999).

13. Oikari, A., Holmbom, B., Bister, H. Annales Zoologici Fennici. 19(1), 61, (1982).

14. Tuurala, H., Soivio, A. Aquat. Toxicol. 2, 21-29, (1982).

15. Oikari, A., Anas, E., Kruzynski, G., Holmbom, B. Bull. Environ. Contam. Toxicol. 33, 233, (1984).

16. Adolfsson- Erici, M. Fish bile in environmental analysis. PhD. Thesis. Stockholm University. Department of applied Environmental Science. Stockholm, Sweden, 2005.

17. Ahmad, I., Fatima, M., Athar, M., Khan, N., Raisuddin, S. Bull. Environ. Contam. Toxicol. 61, 746-753, (1998).

18. Lindesjöö, E., Adolfsson-Erici, M., Ericson, G. And L. Förlin. Ecotox. Environ. Safety 53, 238, (2002).

19. Fox, M.E. J. Fish Res. Board Can. 34, 798, (1977).

20. Martín, V., Yu, Z., Mohn, W. Arch. Microbiol. 172, 131, (1999).

21. Munkittrick, K., Van Der Kraak, G., McMaster, M., Portt, C., van den Heuval, M., Servos, M. Environ. Toxicol. Chem. 13: 1089, (1994). 
22. Volkman, J.K., Holdsworth, D.G., Richardson, D.E. J. Chromatogr. 643, 209, (1993).

23. Quinn, B.P., Booth, M.M., Delfino, J.J., Holm, S.E., Gross, T.S. Environ. Toxicol. Chem. 22 (1): 214, (2003).

24. Khan, R., Payne, J. Chemosphere 46, 235, (2002).

25. Goksoyr, A., Beyer, J., Egaas, E., Grovik, B., Hylland, K., Sandvik, M., Skaare, J. Mar. Poll. Bull. 33 (1-6), 36, (1996).

26. Parada, C., Sobarzo, M., Figueroa, D. Investig. Mar. 29(1): 11, (2001).

27. Corin, N., Backlund, P., Kulovaara, M. Environ. Sci. Technol. 34, 2231, (2000).

28. Johnsen K, K Mattsson, J Tana, TR Stuthridge, J Hemming and K. J. Lehtinen. Environ Toxicol. Chem. 14, 1561, (1995).

29. Heath, A. Water Pollution and Fish Physiology. Second Edition. CRC
Press. U.S.A. Pp. 359, (1995).

30. Zheng, J. and Nicholson, R.A. Environ. Toxicol. Chem. 17, 1852, (1998).

31. Karels A., Markkula E., Oikari A., Environ. Toxicol. Chem, 7, 1517, (2001).

32. Meriläinen PS, A Karels, AOJ Oikari. Monitoring of exposure of fish population to resin acids after accidental release of black liquor from a pulp and paper mill. In Meriläinen P, L Sivula and A. Oikari (eds). Proceedings of Seventh Finnish Conference of Environmental Sciences: Science for sustainability. Jyväskylä, May 12-13, 2005. pp: 80-83, 2005. 